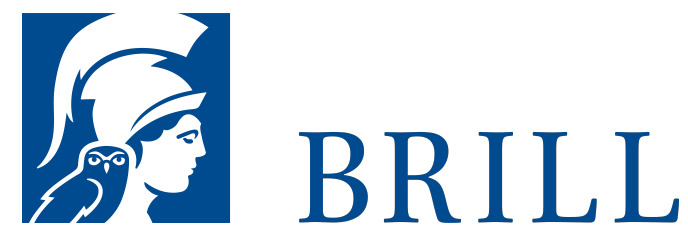

\section{Agricultural Reform and Rural Transformation in China since 1949}

\section{Editors: Thomas DuBois and Huaiyin Li}

Since its founding, the government of the People's Republic of China has strived to transform rural production, the theme of this volume of History of Contemporary China. Fourteen articles translated from the Chinese journal Contemporary History (Dangdai Zhongguo shi yanjiu) offer both empirical account and theoretical analysis of a broad range of historical events and issues, such as the guiding policy framework of the "three rural issues," the causes and consequences of the deep plowing movement and the development of public canteens during the Great Leap Forward, child care, enterprises and collectives, and private lending in the post-Mao era, and the changing dynamics of interregional flows of goods and people throughout the second half of the 2oth century. These studies shed light on the historical origins of some of the agricultural and rural problems in China today.

Readership

The HSCC series will be of interest to the well informed general reader, as well as scholars, researchers and policy makers, in the relevant disciplines and areas of focus on contemporary China.

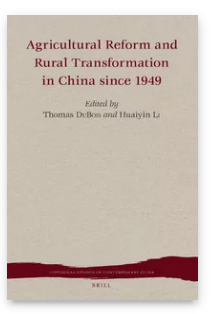

Pages: $\mathrm{x}, 376 \mathrm{pp}$.

Language:

English

Subjects: China, Asian Studies,

Economic

History, History, Social History,

History, Chinese

History, History,

History, Asian

Studies

Publisher: Brill

Series:

Historical

Studies of

Contemporary

China, Volume: 2

E-Book (PDF)

Released online:

$11 \mathrm{Jul} 2016$

ISBN: 978-90-

o4-32249-3

List price

USD \$192.00

Hardback

Publication date:

23 Jun 2016

ISBN: 978-90-

04-29018-1

List price

USD \$192.00 
Thomas David DuBois studied Chinese history at the University of California, Los Angeles, and is currently Senior Research Fellow at the Australian National University. His publications include Empire and the Meaning of Religion in Manchuria, 19001945 (Cambridge University Press 2016), Religion and the Making of Modern East Asia (Cambridge University Press 2011), and Sacred Village: Social Change and Religious Life in Rural North China (University of Hawai'i Press 2005). DuBois is chief editor of the Brill "Historical Studies of Contemporary China" series.

Huaiyin Li received his M.A. from the Graduate School of the Chinese Academy of Social Sciences in 1987 and Ph.D. from UCLA in 2000. He is a professor of history and Asian studies and director of the Center for East Asian Studies at the University of Texas at Austin. His books include Village Governance in North China, 1875-1936 (Stanford, 2005), Village China under Socialism and Reform: A Microhistory, 1948-2008 (Stanford, 2009), and Reinventing Modern China: Imagination and Authenticity in Chinese Historical Writing (Hawai'i, 2013).

For more information see brill.com

Order information: Order online at brill.com +44330 333 oo49 | customerservices@brill.com Submission information: brill.com/authors

Titles published by Brill | Fink, Brill | mentis or Brill | Schöningh: +49(o)71 5413279216 | brill@brocom.de 